\title{
Utilization of Remote Sensing Technology for Flood Distribution in Palembang City Web-based
}

\author{
Indrayani Indrayani ${ }^{1, *}$ Andi Herius ${ }^{1}$, Akhmad Mirza ${ }^{1}$, Arfan Hasan ${ }^{1}$ \\ ${ }^{I}$ Civil Engineering Department, Politeknik Negeri Sriwijaya, Palembang Indonesia \\ *Corresponding author Email: iin_indrayani@polsri.ac.id
}

\begin{abstract}
Construction that continues to be carried out in the city of Palembang, will result in changes to existing land use, more and more swamp areas are stockpiled to build buildings on them, this can certainly have an impact on the reduction of water catchment areas, with the result that when it rains it frequently results in inundation of water in several areas in Palembang City. In the development plan carried out certainly information is needed on flood-prone areas that are spread throughout the city of Palembang, so that a web that can be accessed easily by everyone who needs data on flood distribution areas is needed. The flood distribution map is classified based on interpretation results using remote sensing methods, namely towards inundation, land cover, land slope and rainfall. From the results of the analysis, there are 5 classifications of flood vulnerability levels in the city of Palembang namely a very high level of vulnerability of 16.88 $\mathrm{km}^{2}$, a high level of vulnerability of $888.53 \mathrm{~km}^{2}$, medium vulnerability of $110.03 \mathrm{~km}^{2}$, a low level of vulnerability of $92.73 \mathrm{~km}^{2}$ and not vulnerability of $58.39 \mathrm{~km}^{2}$. Furthermore, the flood distribution map is entered into the flood distribution website which has been designed based on the flood distribution in Palembang City.
\end{abstract}

Keywords: Remote Sensing, Flood, Palembang, WEB-based

\section{INTRODUCTION}

Palembang City is the capital city of South Sumatra Province, located between $2^{\circ} 52^{\prime} 3^{\circ} 5^{\prime}$ South Latitude and $104^{\circ} 37^{\prime} 104^{\circ} 52^{\prime}$ East Longitude. Administratively, the city of Palembang has 18 districts and 107 ward, with an area of $100.61 \mathrm{~km}^{2}$ [3]. Construction that continues to be carried out in the city of Palembang, will result in changes to existing land use, more and more swamp areas are stockpiled to build buildings on them, this can certainly have an impact on the reduction of water catchment areas, with the result that when it rains it frequently results in inundation of water in several areas in Palembang City [7].

Floods in the city of Palembang are not only caused by reduced land area but also due to insufficient drainage capacity, river silting. Changes in flood area in Palembang City can open up the use of remote sensing technology [1][2][6][9][11]. Several studies use land use factors, rainfall, land slope, and topography in determining the flood-prone areas [5][12][13]. Changes in land use certainly have a connection with the intensity of floods that occur in the city of Palembang, where the less air catchment areas will cause an increase in the intensity of floods that occur [4]. Likewise rainfall, an increase of rainfall in an area will cause high flood susceptibility in that area [8][12]. Land slope factors and topography will also affect flood vulnerability in an area, an area that has a low topography will certainly be more prone to flooding [13].

In the development plan carried out, information is needed on flood-prone areas scattered throughout the city of Palembang, so that a web that can be easily accessed by everyone who needs data on flood distribution areas is needed [10]. From the mentioned background, it is necessary to conduct research on the distribution of floods in the city of Palembang based on a web so that it is easier to obtain information on flood-prone areas in the city of Palembang.

\section{METHODOLOGY}

The research was conducted in the city of Palembang which consists of 18 districts and 107 ward and is directly adjacent to Banyuasin Regency in the north, east and west, while in the south is bordered by Muara Enim Regency and Ogan Ilir Regency. The research study area can be seen in Figure 1. 


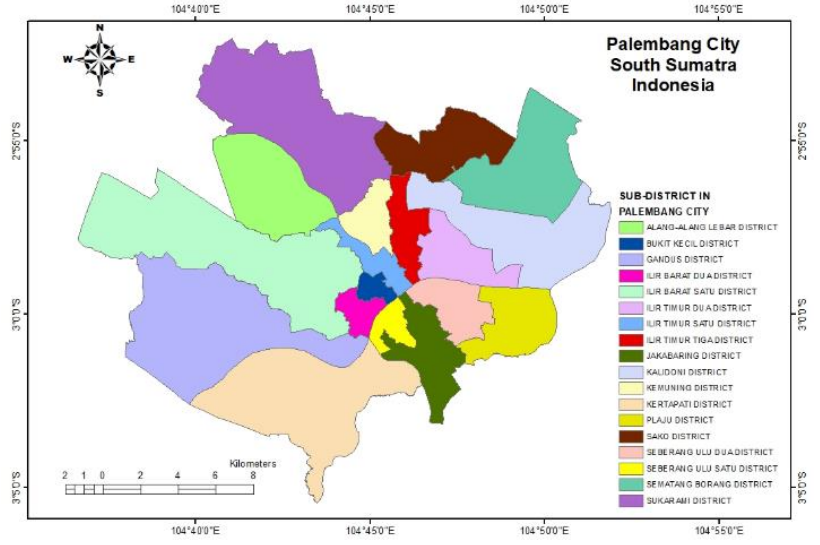

Figure 1. Research Area in Palembang City

The research stages consist of: (i) overlay thematic maps of inundation, land cover, land slope, and rainfall, (ii) website application design, (iii) implementation (insert data and maps to the website), (iv) field test, (v) Palembang city flood distribution website.

\section{RESULT AND DISCUSSION}

\subsection{Classification and scoring of inundation, land cover, land slope, and rainfall}

Entirely thematic maps starting from land cover maps, inundation maps, land slope maps, which are obtained from the interpretation results using remote sensing methods and rainfall maps that already have a score on each classification will be weighted, where each map reviewed has the same weight value which is $25 \%$, this is caused by the components reviewed have the same opportunity in causing flooding in an area.

Maps of classification and scoring of inundation, land cover, land slope, and rainfall can be seen in Figures 2 to 5 .

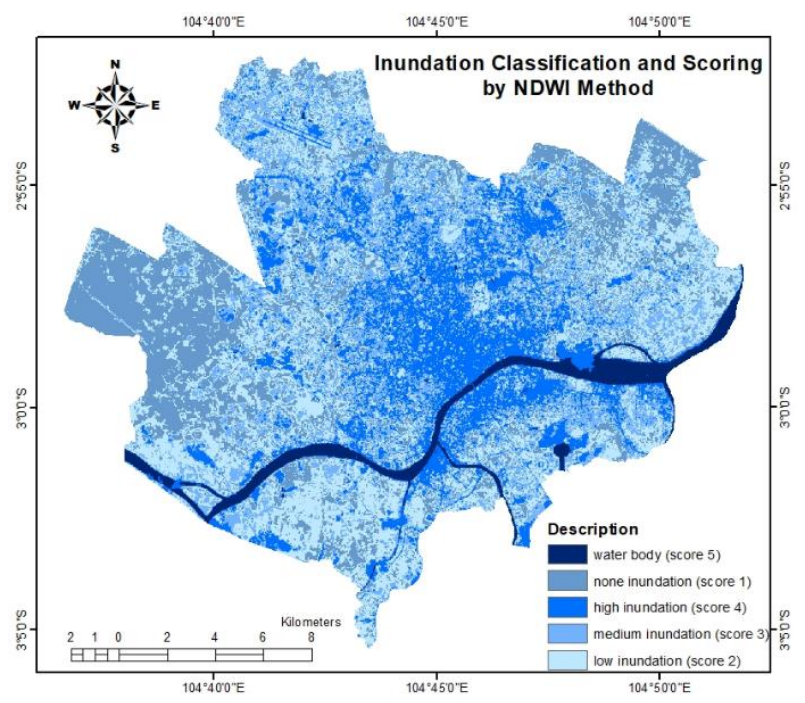

Figure 2. Inundation Classification and Scoring Map

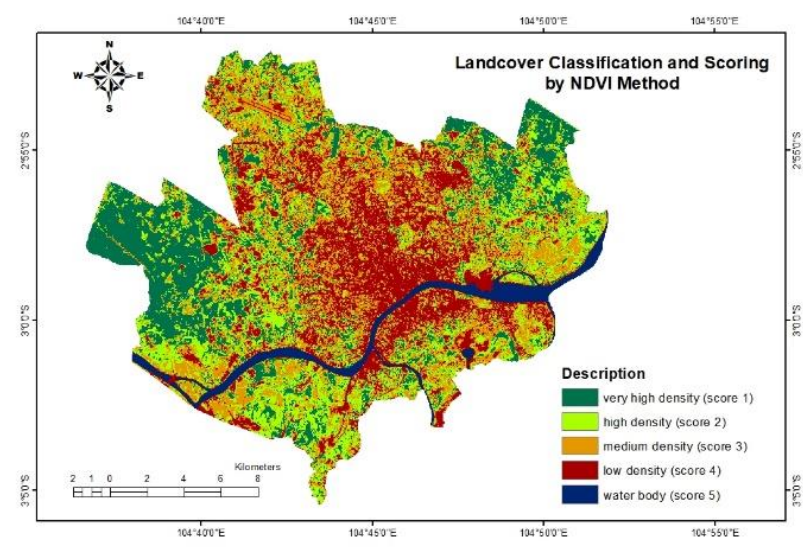

Figure 3. Land Cover Classification and Scoring Map

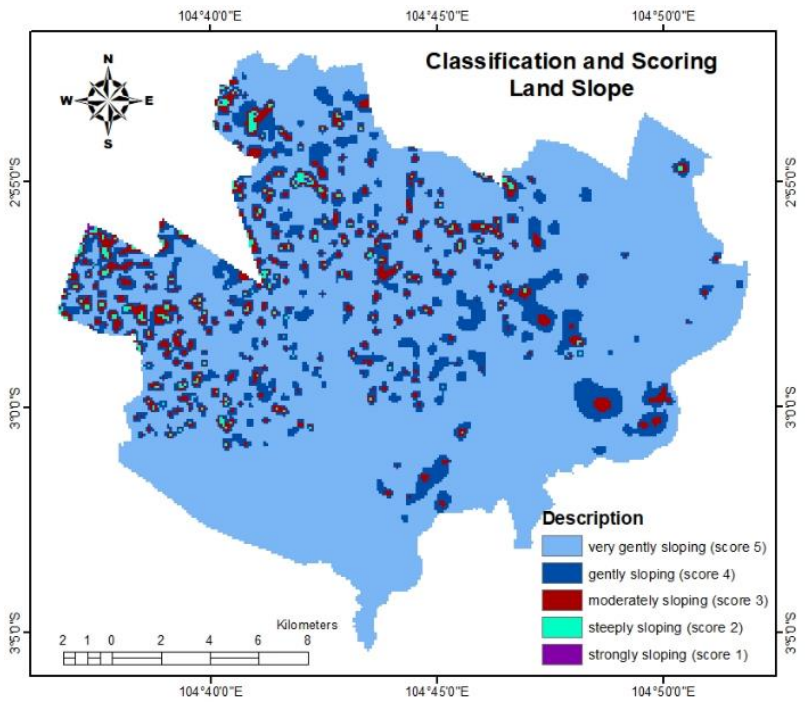

Figure 4. Land Cover Classification and Scoring Map

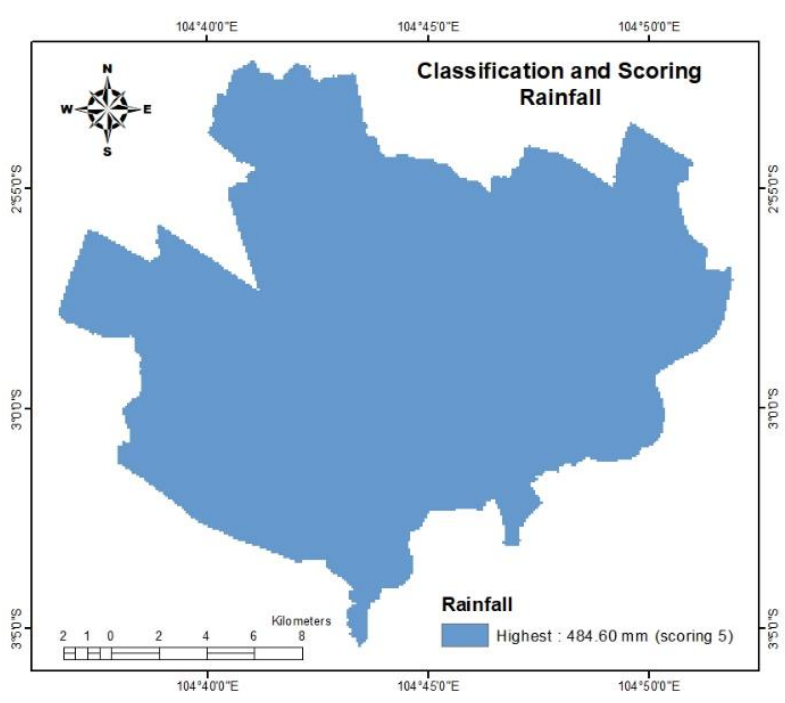

Figure 5. Rainfall Classification and Scoring Map 
Map of flood distribution in Palembang City from the results of weighting and map overlays can be seen in Figure 6.

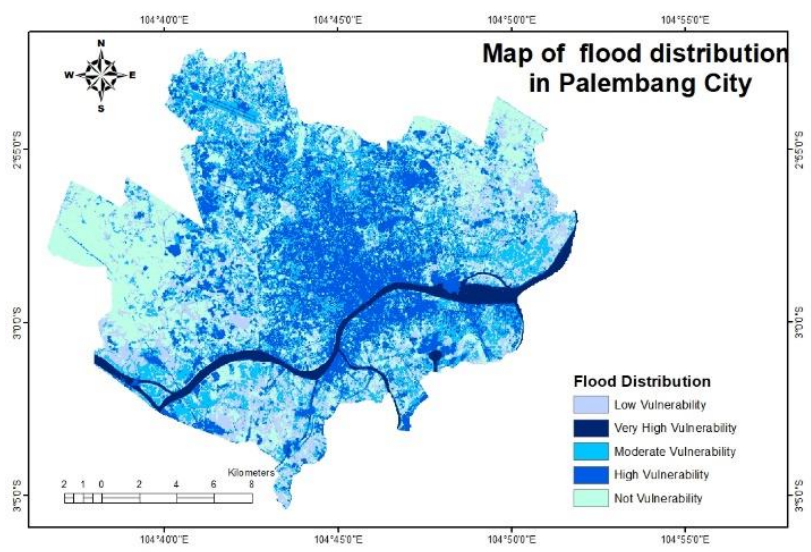

Figure 6. Map of Palembang City Flood Distribution

Furthermore, this flood distribution map will be included in the flood website that will be designed.

\subsection{Website application design}

The design of the flood website application begins with the login page. On the login page there are 2 entries that must be filled in order to enter the main page, namely the registered email and password. If user do not have a registered email and password, they must register an account first by pressing the Register button on the login page, as shown in Figures 7 and 8.

To register an account, there are 6 entries that must be filled, namely full name, telephone number, address, agency, email, and password of user. After completing registration, users can continue surfing the flood website to get the distribution of floods in Palembang City.

LOGIN

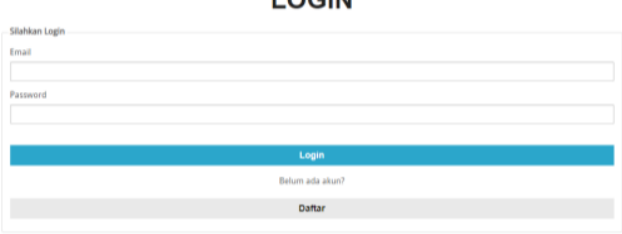

Figure 7. Login Page

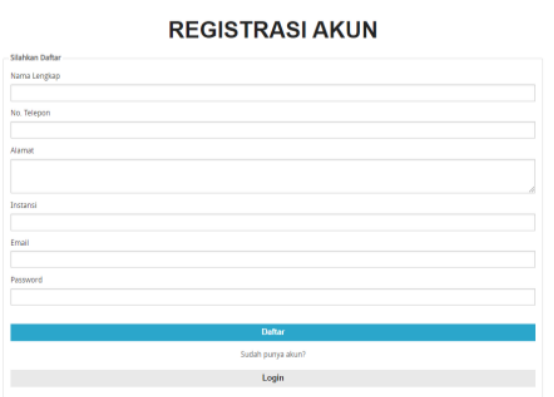

Figure 8. Registration Page

\subsubsection{Home Page}

On the home page there are photos, an explanation of the causes of flooding, an explanation of what InMap Flood is, how to use InMap Flood, and why user should choose InMap Flood. The Home page can be seen in Figure 9.

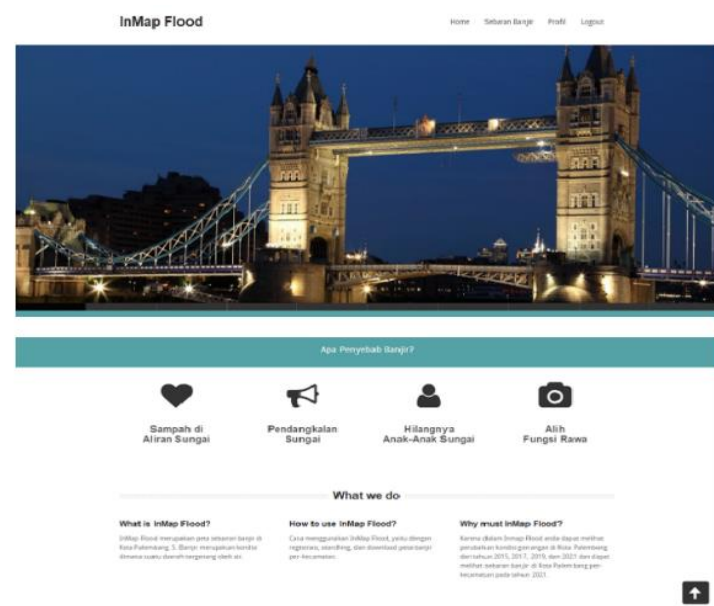

Figure 9. Home Page

\subsubsection{Navigation Bar Menu}

On the navigation bar menu, there are 4 options, namely Home, Flood Distribution, Profile, and Logout. The Home button is used to display the home page. The Flood Distribution button is used to display the list of cities/districts of flood distribution. The Profile button is used to display the page of profile detail, edit profile, and change the password account. The Logout button is used to log the user account out.

\section{Home Sebaran Banjir Profil Logout}

Figure 10. Navigator Bar Menu

\subsubsection{List of City and District Page}

On this page displays a list of the cities and districts in the city. Users can search for the cities by typing name of the city in the search box on the top right. Users can also group the list by city or district by pressing the City or District button. To display the details of the city or district that want to be seen, press the Details button in the middle of the photo of the city/sub-district want to be selected. 


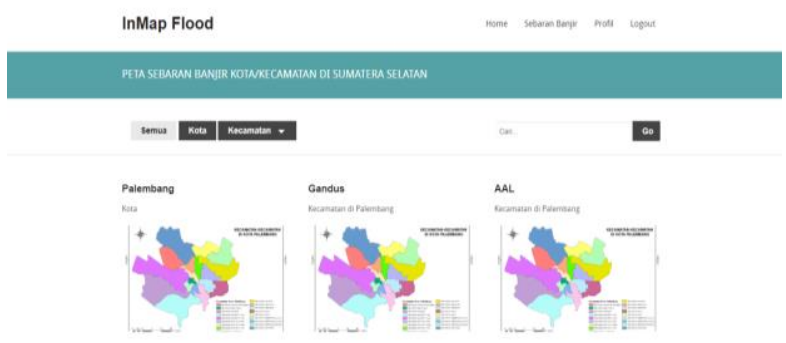

Figure 11. List of City and District Page

\subsubsection{Detail of City and District Page}

On this page displays detailed information from the city/district which includes maps and photos of the flood distribution, and the address of the mayor's/district office. If the user selects city details, then user can select detailed information by year. Users can also download photos of flood distributions by pressing the Download Image button.

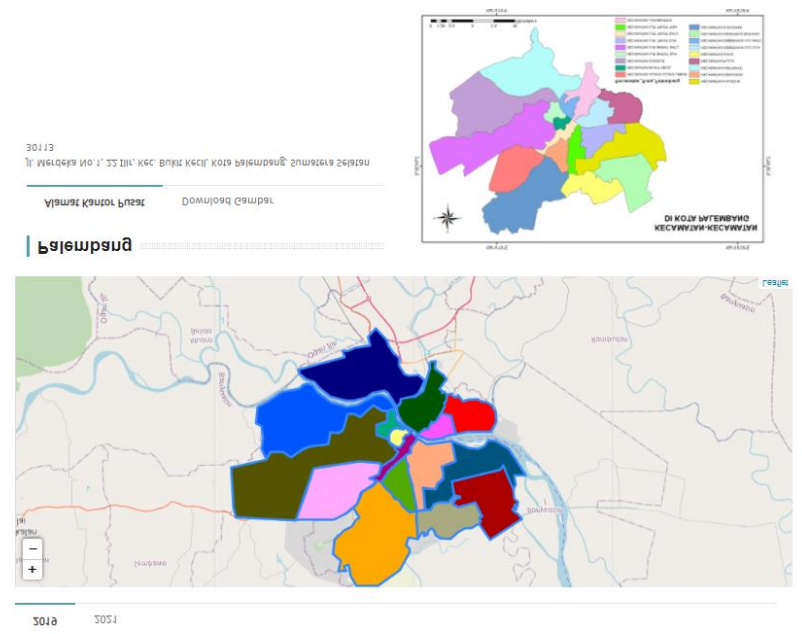

Figure 12. Detail of City and District Page

\subsubsection{Profile Page}

InMap Flood

\section{Protl Saya}

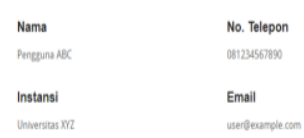

Figure 13. Profile Page

On this page displays user profile details when registering. Users can access their profiles by pressing the Edit Profile button. Users can also change their account passwords by pressing the Change Password button.

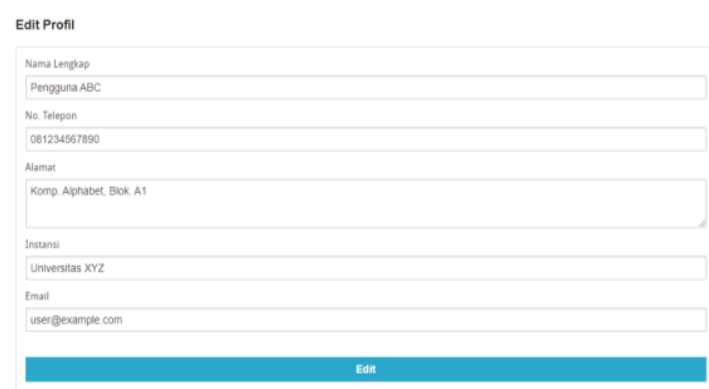

Figure 14. Edit Profil on Profile Page

The profile edit form will appear if the user presses the Edit Profile button. Users can change their name, phone number, address, agency, and email.

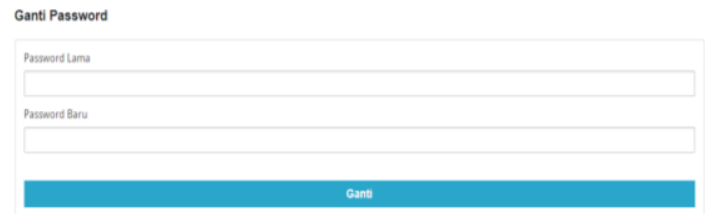

Figure 15. Change Password Account on Profile Page

The change password form will appear if the user presses the Change Password button. The user must enter the old password first to change the password.

From the stages of using the web above, it is expected that users who need data on the distribution of floods in the city of Palembang can easily access the locations of the distribution of floods in the districts of the city of Palembang, ranging from very high vulnerability, high vulnerability, medium vulnerability, low vulnerability, and not vulnerable flood. Information on this potential flood area will be highly needed in regional planning, road planning, land purchase planning, and so forth.

\subsection{Discussion}

Previous research on determining the distribution of floods using a geographic information system $[8][9][11][12][13]$ was not followed up with the creation of a WEB so that information about the distribution of floods was more difficult to access by the general public. With this flood web, all parties can access the flood distribution web site in Palembang City.

\section{CONCLUSIONS}

From the results of the analysis, there are 5 classifications of flood vulnerability levels in the city of Palembang namely a very high level of vulnerability of $16.88 \mathrm{~km}^{2}$, a high level of vulnerability of $888.53 \mathrm{~km}^{2}$, 
medium vulnerability of $110.03 \mathrm{~km}^{2}$, a low level of vulnerability of $92.73 \mathrm{~km}^{2}$ and not vulnerability of 58.39 $\mathrm{km}^{2}$. Furthermore, the flood distribution map is entered into the flood distribution website which has been designed based on the flood distribution in Palembang City.

\section{ACKNOWLEDGMENTS}

Thank you to Politeknik Negeri Sriwijaya for funding the assignment research scheme from the Politeknik Negeri Sriwijaya DIPA funding.

\section{REFERENCES}

[1] Ariyora, Y.K.S., Budisusanto, Y., Prasasti, I., 2015. Pemanfaatan Data Penginderaan Jauh dan SIG untuk Analisa Banjir (Studi Kasus: Banjir Provinsi DKI Jakarta). GEOID, Vol. 10, No. 02, pp 137-146.

[2] Assatse, W.T., Nouck, P.N., Tabot, C.T., Akame, J.M., Biringanine, G.N., 2015. Hydrogeological Activity of Lineaments in Yaounde Cameroon Region Using Remote Sensing and GIS Techniques. The Egyptian Journal of Remote Sensing and Space Sciences, Elsevier: 1 - 12, www.sciencedirect.com.

[3] BPS Kota Palembang, 2020. Palembang Dalam Angka, Badan Pusat Statistik Kota Palembang.

[4] Indrayani., Buchari, E., Putranto, D.D.A., Saleh, E., 2017. Analysis of landuse in the Banyuasin district using the image Landsat 8 by NDVI method. AIP Conference Proceedings 1903, 030007, https://doi.org/10.1063/1.5011514.

[5] Indrayani., Buchari, E., Putranto, D.D.A., Saleh, E., 2018a. The analysis of landuse weights on road traces selection., https://doi.org/10.1051/ matecconf/201819504018.
[6] Indrayani., Buchari, E., Putranto, D.D.A., Saleh, E., 2018b. Analysis of Puddles in swamp area of Banyuasin District using the imange Landsat 8 by NDWI method., Ecology, Environment and Conservation, Vol.24, No.3: 1069-1075, ISSN 0971 $-765 \mathrm{X}$.

[7] Indrayani, 2021. Trase Jalan pada Daerah Rawa Berbasis Spasial. Pustaka Aksara, Surabaya.

[8] Laurensz, B., Lawalata, F., Prasetyo, S.Y.J., 2019. Potensi Resiko Banjir dengan Menggunakan Citra Satelit (Studi Kasus: Kota Manado, Provinsi Sulawesi Utara). Indonesian Journal of Modeling and Computing, pp: 17-24, eISSN: 2598-9421.

[9] Muamanah, S.B., 2019. Pemanfaatan Citra Penginderaan Jauh untuk Mengetahui Daerah Rawan Banjir di Kabupaten Lamongan sebagai Bentuk Mitigasi Bencana di Kabupaten Lamongan Sebagai Bentuk Mitigasi Bencana. https://www. researchgate.net/publication/337253848.

[10] Sibero, A.F.K., 2014. Kitab Suci Web Programing. Jakarta: Mediakom.

[11] Utomo, P.P, Riadi, B., Ramdani, D., 2020. Identifikasi Sebaran Banjir Menggunakan Citra Satelit Sentinel-1. Program Studi Teknik Geodesi, Fakultas Teknik, Universitas Pakuan.

[12] Hamdani,H., Permana,S., Susetyaningsih, A., 2014. "Analisa Dearah Rawan Banjir Menggunakan Aplikasi Sistem Informasi Geografis (Studi Kasus Pulau Bangka)”. Jurnal Konstruksi Sekolah Tinggi Teknologi Garut, vol. 12, No. 1, ISSN:2302-7312.

[13] Tampubolon, K., 2018. Aplikasi Sistem Informasi Geografis sebagai Penentu Kawasan Rawan Banjir di Kota Medan. Jurnal Pembangunan Perkotaan, Vol. 6, No. 2, e-ISSN: 2581-1304. 